DOI: $10.15290 /$ bsl.2019.14.10

\author{
Barbara Tyszkiewicz \\ Instytut Badań Literackich PAN \\ e-mail: barbara.tyszkiewicz@ibl.waw.pl \\ ORCID: 0000-0002-7214-2433
}

\title{
Kantata anielska, czyli polemiczny dialog Zawieyskiego z Andrzejewskim
}

$\mathrm{Na}$ początku października 1945 roku na pierwszych stronach tygodnika „Odrodzenie” ukazał się obszerny artykuł Jerzego Andrzejewskiego pt. Propozycje teraźniejszości ${ }^{1}$. Trzydziestosześcioletni pisarz analizował charakter zmian, jakie zachwiały społecznym i moralnym ładem ówczesnego świata, a jemu samemu narzucały inne spojrzenie na rzeczywistość. Rozmyślając nad ogromem zniszczeń i bezsensownych śmierci, które pociągnęła za sobą druga wojna światowa, skłonny był postawić tezę o agonii katolicyzmu. Miejsce po umarłej religii wyznaczał marksizmowi ${ }^{2}$. Było to daleko idące przewartościowanie poglądów, którym kilka lat wcześniej dał artystyczny wyraz w powieści Ład serca ${ }^{3}$.

1 J. Andrzejewski, Propozycje teraźniejszości, „Odrodzenie” 1945, nr 45, s. 1, 2.

2 Uwarunkowania i zawiłości tej biograficznej wolty monografistka pisarza Anna Synoradzka ujmowała następująco: „,[Andrzejewski] powtórzył tam [tj. w Propozycjach teraźniejszości] jeszcze swe przekonanie, że marksizm nie może usatysfakcjonować twórcy starającego się postrzegać człowieka w całej złożoności duchowo-cielesnej, ale stwierdził też, że dostrzega «społeczną» użyteczność etyki wynikającej z filozofii marksistowskiej, jako kompetentnej w ocenie zjawisk «obiektywnie sprawdzalnych». W gruncie rzeczy przyznawał rację swemu niedawnemu adwersarzowi [tj. Janowi Kottowi]. «Dojrzewał» do przejęcia obowiązującej ideologii za własną". A. Synoradzka, Andrzejewski, Kraków 1997, s. 84. Wtrącenia w nawiasach, zarówno w tekście głównym, jak i przypisach, jeśli nie zaznaczono inaczej, pochodzą od autorki artykułu.

3 J. Andrzejewski, Ład serca. Powieść, „Prosto z mostu” 1937, nr 46-57, 1938, nr 1-21. Wyd. osobne: Warszawa 1938; wyd. nast.: 1939. 
Odsuniętą w czasie reakcją na Propozycje teraźniejszości była Kantata anielska, obszerny esej z podtytułem List do Jerzego Andrzejewskiego i do „Katechumenów"4, ogłoszony w styczniu 1948 roku przez Jerzego Zawieyskiego. Główny adresat "listu" nie udzielił drukowanej odpowiedzi. Czy to znaczy, że zignorował nadawcę i samo przesłanie? Czy uznał, że Kantata ukazała się za późno? Jakie relacje łączyły wówczas obu autorów i co z nich przenikało do ich twórczości? Jak postrzegali nurt katolicki w literaturze i swoje w nim role? $\mathrm{W}$ jaki sposób ideowe wybory przekładały się na ich wyobrażenia o sztuce i powołaniu artysty? Czy udało im się znaleźć płaszczyznę porozumienia $\mathrm{w}$ tej kwestii? Próba przybliżenia problematyki zawartej $\mathrm{w}$ tych pytaniach wiąże się z odsłanianiem biograficznych niuansów, które nabierają wagi dopiero z odległej perspektywy.

\section{Między Bąkiem a Żółkiewskim}

Pierwsze głosy dotyczące Propozycji teraźniejszości pojawiły w listopadzie 1945 roku: najpierw Wojciecha Bąka ${ }^{5}$, przedstawiciela opcji katolickiej, nieco później - Stefana Żółkiewskiego ${ }^{6}$, rzecznika ideologii kształtującej Polskę Ludową. Oba stanowiska opierały się na przekonaniu, że środowiska katolickie tracą autora, który całkiem niedawno zyskał status ich reprezentanta. Różniły się podejściem do tego faktu.

Bąk doceniał artystyczne walory Propozycji teraźniejszości, krytykował natomiast anachroniczne - jego zdaniem - zrównanie statusu religii i doktryny naukowej. Odniósł się także do metafory koni trojańskich, użytej przez Andrzejewskiego dla zobrazowania charakteru swego (wraz z innymi intelektualistami) zbliżenia do Kościoła. Nie polemizując z tą autooceną, zwracał uwagę, że zaangażowanie intelektualistów po stronie marksizmu może być jeszcze bardziej destrukcyjne w skutkach.

Żółkiewski o takim zagrożeniu w ogóle nie wspominał. Odbierał artykuł jako "podkreślenie moralnych wartości marksistowskiego poglądu” i akces do współtworzenia nowej sztuki, zrywającej z burżuazyjnymi modelami międzywojnia. Z publicystą "Odry” zgadzał się co do jednego: że rozważanie marksizmu i katolicyzmu na jednej płaszczyźnie jest błędem. Zamiast proponowanego przez Bąka rozróżnienia i hierarchizacji obu po-

\footnotetext{
4 J. Zawieyski, Kantata anielska. List do Jerzego Andrzejewskiego i do „Katechumenów”, ,Tygodnik Powszechny" 1948, nr 4, s. 1, 3. Przedr. w: tegoż, Droga katechumena, Warszawa 1971, s. 3-15.

5 W. Bąk, Konie trojańskie, "Odra” 1945, nr 8, s. 3.

6 S. Żółkiewski, Głos marksisty, „Odrodzenie” 1945, nr 51, s. 1.
} 
jęć, stanowczo nakazywał: „Kto wybrał marksizm - katolicyzm musi odrzucić" 7 .

W grudniu, w tygodniku „Dziś i Jutro”, kształtowanym przez myśl polityczną Bolesława Piaseckiego, ogłosił recenzję Ludwik Baranowski ${ }^{8}$. Dla spolaryzowanej już $w$ listopadzie recepcji tekstu nie miała ona większego znaczenia. Tymczasem Zawieyski czekał jeszcze ponad dwa lata, by podjąć wyczerpany, zdawałoby się, temat. Był o siedem lat starszy od Andrzejewskiego, a jako dramatopisarz i prozaik mógł się z nim równać rangą osiągnięć literackich. Co ważne - również miał za sobą światopoglądowy przełom. Wybór, którego dokonał na początku lat 40., był zaprzeczeniem decyzji Andrzejewskiego przedstawionej w Propozycjach teraźniejszości. Po dwóch dekadach funkcjonowania w kręgu myśli lewicowej Zawieyski wrócił do religii, w której został wychowany.

\section{Z historii znajomości}

$\mathrm{W}$ rodzinnym domu na robotniczych peryferiach Łodzi otaczał Zawieyskiego żarliwy katolicyzm. Zerwanie z religią było przejawem młodzieńczego buntu wobec nieszczęść, które stopniowo rujnowały szczęśliwe dzieciństwo chłopca. Osierocony przez ojca, w skrajnej biedzie przetrwał pierwszą wojnę światową, a potem, skonfliktowany z ojczymem, zamieszkał samotnie i zbliżył się do środowisk lewicowych. Jako adept szkoły aktorskiej związał się z Towarzystwem Uniwersytetu Robotniczego w Łodzi, a później ze Związkiem Młodzieży Wiejskiej „Wici”. Pozostając w kręgu oddziaływania ruchu ludowego z początkiem lat 30. objął stanowisko dyrektora Instytutu Teatrów Ludowych. W jego pierwszych powieściach ${ }^{9} \mathrm{i}$ dramatach ${ }^{10}$ widoczna była fascynacja pisarstwem Stefana Żeromskiego. Dopiero w okresie okupacji znów poczuł się członkiem Kościoła, a u schyłku drugiej wojny światowej (po krakowskiej premierze dramatu o Hiobie) ${ }^{11}$ zaczął być postrzegany przez krytykę jako znaczący przedstawiciel nurtu katolickiego w literaturze.

7 Tamże.

8 L. Baranowski, Katastrofizm Andrzejewskiego, „Dziś i Jutro” 1945, nr 3, s. 3-4.

9 J. Zawieyski, Gdzie jesteś, przyjacielu?... Warszawa 1932. Wyd. nast.: Warszawa 1956; Daleko do rana, Warszawa 1934.

10 Najdobitniej zaznaczyło się to w sztuce Powrót Przełęckiego. Dalsze losy bohaterów komedii St. Żeromskiego pt. "Uciekła mi przepióreczka...", wystawionej (w reżyserii i z główną rolą Juliusza Osterwy) w Teatrze Narodowym w Warszawie; premiera 16 kwietnia 1937. Wydanie: Warszawa 1960.

11 J. Zawieyski, Mąż doskonały. Premiera: Kraków, Stary Teatr, 1 IV 1945. 
Wczesną wiosną 1945 roku Zawieyski i Andrzejewski zostali sąsiadami w domu przy ulicy Krupniczej 22 w Krakowie. Mieszcząca się pod tym adresem siedziba władz Związku Zawodowego Literatów Polskich (ZZLP) na kilkanaście miesięcy stała się ich wspólnym domem. Dzielili go z wieloma innymi twórcami, pozbawionymi własnych mieszkań na skutek działań wojennych ${ }^{12}$. Na początku października tegoż roku Andrzejewski został prezesem Krakowskiego Oddziału ZZLP, a Zawieyski - wiceprezesem. Obaj sprawdzali się w tych rolach, a efekty ich współpracy doceniali ludzie kultury. Ludwik Solski wspominał:

Dnia 9 stycznia [1946 r.] przyjęty byłem przez Związek Literatów. Ówczesny prezes krakowskiego oddziału Jerzy Andrzejewski dziękował mi za wieloletnią pomoc udzieloną pisarzom polskim na scenie. O tej pomocy mówił też później [Ludwik Hieronim] Morstin na podstawie osobistych wspomnień. Podobny charakter miały gawędy [Jerzego] Szaniawskiego i [Krystyny] Grzybowskiej. Na zakończenie Jerzy Zawieyski odczytał kilka moich wierszy. Potem była dobra czarna kawa, jeszcze lepsze wino a najlepsza - przyjacielska atmosfera ${ }^{13}$.

Ich prywatne relacje nabrały przyjacielskiego, wręcz familiarnego charakteru. W dyskusjach o sztuce nie szczędzili sobie krytyki i znacząco różnili się $\mathrm{w}$ poglądach na temat pożądanych kierunków rozwoju literatury. Zawieyski odniósł sukces jako autor Męża doskonałego, którym Stary Teatr w Krakowie zainaugurował pierwszy, powojenny sezon. Później miał trudności z wydaniem okupacyjnych powieści ${ }^{14}$ i martwił się, że jego dramat historyczny pt. Masław przeszedł bez echa ${ }^{15}$. Na początku 1946 roku dostał do rąk nowy tom prozy Andrzejewskiego pt. Noc, na który złożyły się opowiadania Przed sądem, Apel i Wielki Tydzień. Wrażeniami z tej lektury podzielił się ze swym życiowym partnerem, Stanisławem Trębaczkiewiczem, pisząc m.in.:

12 Mieszkali tu wówczas m.in. Kazimierz Brandys, Tadeusz Breza, Stanisław Dygat, Leon Kruczkowski, Czesław Miłosz, Stefan Otwinowski, Helena Wielowieyska, Kazimierz Wyka, Xenia Żytomirska.

13 L. Solski (Ludwik Napoleon Sosnowski), Wspomnienia 1. Na podstawie rozmów napisał Alfred Woycicki, t. 2: 1899-1954, Kraków 1956, s. 486.

14 Droga do domu, wydana nakładem warszawskiej oficyny E. Kuthana, po problemach z kolportażem trafiła do księgarń w kwietniu 1946 r., a w 1949 temu samemu wydawcy udało się sfinalizować jej drugie wydanie. Noc Huberta pojawiła się w sprzedaży w końcu grudnia 1946 r., a w skróconej wersji przedrukowana została w tomie Pokój głębi, Poznań 1956.

15 J. Zawieyski, Masław. Premiera: Kraków, Stary Teatr, 19 XII 1945. Warto zaznaczyć, że sztuka ta otrzymała pierwszą nagrodę $\mathrm{w}$ konspiracyjnym konkursie dramatycznym zorganizowanym w Warszawie w 1942 r., a dwa lata później to samo wyróżnienie zdobył dramat pt. Dzień sądu (o wyroku wydanym na Chrystusa przez Poncjusza Piłata). Komedia Święto Winkelrieda, autorstwa Andrzejewskiego i Jerzego Zagórskiego, zgłoszona do konkursu w 1944 r., nie otrzymała żadnego wyróżnienia. 
Czytałem Noc Andrzejewskiego z wielkim rozczarowaniem. To jest poza literaturą i sztuką. Wielki Tydzień to reportaż z gazety, banalny, łatwizny i kopiowanie rzeczywistości. Tak, jak mnie nie podoba się jego książka, jemu nie będzie się podobała moja. On twierdzi, że moja proza nie jest prozą, tak jak moje dramaty mało mają dramatyczności. Muszę się z tym rozprawić teoretycznie, tylko tak się rozleniwiłem, że nic mi się nie chce pisać ${ }^{16}$.

\section{Andrzejewski - od katechumena do marksisty}

Publicystyczny ton Wielkiego Tygodnia wpisywał się w model kultury forsowany przez władze. Było to widoczne zwłaszcza dla tych czytelników, którzy pamiętali, że jeszcze latem 1945 roku Andrzejewski polemizował z Janem Kottem, hołdującym doktrynie materializmu dialektycznego. Jako autor opowiadania Przed sq̨dem domagał się wówczas, aby w interpretacji tego utworu uwzględniać nie tylko sferę faktów przedstawionych, lecz także niematerialne uwarunkowania i duchowy wymiar zarysowanych konfliktów ${ }^{17}$. Kilka tygodni później, w Propozycjach teraźniejszości twierdził już, że młoda myśl marksistowska jest jedynym fundamentem zdolnym udźwignąć budowę powojennego ładu społecznego, moralnego i estetycznego. Stawiając tę tezę, wyraźnie zaznaczał, że przed 1939 rokiem myślał inaczej.

W okresie, gdy pisał Ład serca, uważał się za katechumena. Precyzował, że mówi o tych intelektualistach, którzy nie tyle należeli do wspólnoty wierzących, co "ciążyli w stronę Kościoła" i stanowili swoistą sektę jego intelektualnych przyjaciół ${ }^{18}$. Jako niezdolni do przyjęcia religijnych objawień i dogmatów, odegrali wobec katolików podobną rolę, jak niegdyś mityczny koń Odyseusza wobec mieszkańców Troi. Doprowadzili do zniszczenia mistycznego wymiaru Kościoła i powinni z niego odejść. Nawet wówczas, gdy nie widzieli dla siebie innej alternatywy i skazywali się na samotność.

Na logikę tego wywodu Andrzejewski nakładał filozoficzną refleksję nad najnowszą historią. Przekonywał, że jeszcze do niedawna katolicy i marksiści - jako dwie równorzędne siły - jednoczyli się $\mathrm{w}$ walce $\mathrm{z}$ faszyzmem.

\footnotetext{
16 J. Zawieyski, List do Stanisława Trębaczkiewicza z 23 I 1946 r. Rękopis w Bibliotece Ossolineum we Wrocławiu, 16453/II wol. 1, s. 123.

17 Zob. J. Kott, Rozmowa, „Odrodzenie” 1945, nr 36, polem.: J. Andrzejewski, O obrone człowieka, „Odrodzenie” 1945, nr 38.

18 J. Andrzejewski, Propozycje teraźniejszości, s. 1. Tu m.in.: „większość współczesnych intelektualistów albo dokonuje wyboru pomiędzy Kościołem i marksizmem, albo, nie mogąc zdobyć się na wybór pełny i ostateczny, krąży dookoła jednego z dwóch światopoglądów, względnie skłania się na przemian ku obydwom. Trudno stwierdzić, kogo jest więcej: wyznawców, czy mówiąc językiem - liturgii, katechumenów?".
} 
Po odniesieniu zwycięstwa podzieliła ich głęboka przepaść, aż w końcu stanęli do konfrontacji. Wygranym w tym starciu okazał się materializm dziejowy, bo zamiast metafizyki i rozwiązań ostatecznych proponował jasną wizję przyszłości opartej na przemianach społeczno-ekonomicznych i obiektywnej analizie zjawisk. „Historyczna era religii chrześcijańskiej kona na naszych oczach" 19 - diagnozował pisarz i choć spodziewał się, że agonia może jeszcze potrwać, to jest nieunikniona.

Wybierając marksizm, Andrzejewski nie spieszył się z uzyskaniem partyjnej legitymacji ${ }^{20}$. Konsekwencje podjętej decyzji dostrzegalne były $\mathrm{w}$ jego utworach, coraz wyraźniej wpisujących się w politykę kulturalną państwa. W 1946 roku tom Noc został wyróżniony nagrodą miasta Krakowa, a jego autor był postrzegany jako twórca "postępowy" i publicznie tej opinii nie kontestował. W sferze prywatnej absorbowały go sprawy rodzinne, a więc zawarte w styczniu 1946 roku małżeństwo z Marią Abgarowicz-Czyściecką, dzieci (syn Marcin, urodzony w 1943 roku i córka Agnieszka Eugenia, urodzona jesienią 1946 roku). Ojcem chrzestnym pierwszego dziecka był Krzysztof Kamil Baczyński, drugiego - Jerzy Zawieyski.

\section{Zawieyskiego dojrzewanie do polemiki}

Do roli ojca chrzestnego córki Andrzejewskiego poproszony został pisarz, który wiosną 1947 roku ogłosił esej pt. Zagadnienie literatury katolickiej21. Był to rodzaj artystycznego manifestu, w którym punkt wyjścia stanowiły filozoficzne założenia katolickiego personalizmu w ujęciu Jacquesa Maritana (przedstawione w książce Sztuka $i$ mądrość) 22. Proste rozpoznanie, że specyfika literatury katolickiej wynika $\mathrm{z}$,zasady postulatywnej i normatywnej: zgodności życia pisarza i jego dzieła" ${ }^{23}$, było jednak dla Zawieyskiego niewystarczające. Wartości dzieła literackiego upatrywał w tym, że pokazuje ono człowieka, który podlega jednocześnie prawom ziemskim i nadprzyrodzonym, a napięcie między tymi porządkami kształtuje jego życie wewnętrzne. Rozwijając tę myśl, pisał:

\footnotetext{
19 J. Andrzejewski, Propozycje teraźniejszości, s. 1.

20 Członkiem PZPR Andrzejewski został dopiero w 1950 roku.

21 J. Zawieyski, Zagadnienie literatury katolickiej, "Tygodnik Powszechny” 1947, nr 23, s. 1, 3-4 (przedruk w: J. Zawieyski, Droga katechumena, Warszawa 1971, s. 128-151).

22 J. Maritain, Sztuka i mądrość, przeł. Konrad i Karol Górscy, Poznań [1936]. W oryginale rzecz ukazała się po raz pierwszy w 1920 r. w Paryżu pt. Art et scolastique.

23 J. Zawieyski, Zagadnienie literatury katolickiej, s. 4.
} 
Na tej dążności do ładu, wyrażonej środkami sztuki dalekimi od moralizmu, będzie piętno owego sensus catholicus. Zasada życia wewnętrznego człowieka odróżni literaturę katolicką od niekatolickiej, zwłaszcza postulowanej marksistowskiej, dla której życie wewnętrzne jest tylko mitologią i fantastyką ${ }^{24}$.

Poczucie tragizmu leżące u źródeł sztuki było - zdaniem eseisty - konsekwencją tego, że "obok dążenia do Boga jest w nas równie silny opór względem niego, obok miłości żyje w nas - nienawiść, obok dobra - zło i cierpienie" 25 . Sprowadzanie jednostkowego bytu do elementu życia społecznego oznaczało (w koncepcji Zawieyskiego) niwelowanie pierwiastka tragicznego, a co za tym idzie - spłycało artystyczną twórczość, eliminując z niej duchowy wymiar egzystencji.

Można przyjąć, że Zagadnienie literatury katolickiej stanowiło (jakąś pośrednią) formę polemicznego dyskursu z Propozycjami teraźniejszości. Chrzciny, które odbyły się rok po narodzinach Agnieszki Andrzejewskiej ${ }^{26}$, dały ojcu chrzestnemu asumpt do ponownych przemyśleń nad tekstem ogłoszonym jesienią 1945 roku. Cieszyło go, że matka dziecka żywo zareagowała na powieść pt. Droga do domu, w której pisał o dojrzewaniu do katolicyzmu ${ }^{27}$. Ideowa deklaracja Andrzejewskiego rysowała mu się teraz w nowym - bardziej personalnym, niż literackim - wymiarze. Zapewne miał ją w pamięci, gdy w październiku 1947 roku pojechał do podwarszawskich Lasek ${ }^{28}$. Po raz pierwszy zobaczył wówczas zakład dla niewidomych i ośrodek myśli religijnej prowadzony przez Zgromadzenie Sióstr Franciszkanek Służebnic Krzyża. Wiedział, że w drugiej połowie lat 30., gdy ksiądz Władysław Korniłowicz redagował tutaj kwartalnik kulturalno-religijny „Verbum”, Andrzejewski kilkukrotnie gościł w Laskach w charakterze katechumena ${ }^{29}$.

\footnotetext{
24 Tamże.

25 Tamże.
}

26 Zob. J. Zawieyski, List do Zofii Nałkowskiej z 30 IX 1947 r., w: "Niesie mnie rzeka smutku...” Korespondencja Zofii Nałkowskiej i Jerzego Zawieyskiego 1943-1954, Warszawa 2000, s. 153. Tu m.in.: „Chciałbym na trzy dni wpaść do Krakowa, bo nie widziałem ani jednej próby [Ocalenia Jakuba] i mam być ojcem chrzestnym córki Andrzejewskiego".

27 Tuż po ukazaniu się Drogi do domu, Zawieyski pisał do Trębaczkiewicza, że „największą przyjemność sprawił mi list żony Andrzejewskiego, która przeżyła głęboko moją książkę". J. Zawieyski, List do S. Trębaczkiewicza z 21 III 1946 r., Ossolineum 16453/II wol. 1, s. 139-140.

28 W liście do przyjaciela tak o tym pisał: „W tej chwili jestem zmęczony, mam zamęt w głowie. Jutro jadę do Lasek, aby trochę odpocząć i poznać nowych ludzi i nowe, niezwykłe miejsce ludzkiej pracy" [J. Zawieyski, List do S. Trębaczkiewicza z 5 IX 1947 r., Ossolineum 16453/II vol. 1, s. 365].

29 Szerzej na ten temat zob. A. Synoradzka-Demadre, Andrzejewski w poszukiwaniu ładu wewnętrznego (1937), w: tejże, Jerzy Andrzejewski. Przyczynek do biografii prywatnej, Warszawa 2016, s. 82-90. 
Zawieyski odwiedził to miejsce dziesięć lat później i wrócił do domu zauroczony panującą tam atmosferą. Laski wspominał potem jako swoją "duchową ojczyznę" ${ }^{30}, \mathrm{w}$ której zgłębiał istotę katolicyzmu i uczył się, jak spieszyć z pomocą ociemniałym "na ciele i duszy”. To stąd wyniósł przeświadczenie, że potrafi mówić o Bogu $\mathrm{w}$ tonie odbiegającym od kaznodziejskiej nauki, łączyć filozoficzny wywód z przystępną dla wielu czytelników formą eseju. Okazji do dyskursu z marksistami dostarczył mu (odbywający się w listopadzie 1947 roku) zjazd Związku Zawodowego Literatów Polskich we Wrocławiu. O słownym pojedynku, który stoczył tam z Żółkiewskim, tak później donosił Trębaczkiewiczowi:

A teraz opiszę Ci o zjeździe. Odniosłem niebywały sukces, jakiego dotąd $\mathrm{w}$ środowisku pisarzy nie odniosłem. Miałem wielką mowę w dyskusji z [Stefanem] Żółkiewskim, po jego referacie. Takiej mowy odważnej, filozoficznej, na wielkim poziomie dotąd nie wygłosiłem. Trudno mi Ci pisać o szczegółach, ale zjadłem Żółk.[iewskiego] i marksizm do kosteczek. Gratulowali mi wszyscy i ściskali, nawet marksiści, Kazio [Brandys] i Matuszewski i różni, różni. Żółk.[iewski] w odpowiedzi powiedział bardzo rzewnie, że jeśli jest przepaść między nami, to on gotów tę przepaść przeskoczyć, aby znaleźć się w moich objęciach. Mówił, że jest pod moim urokiem, jako pisarza i człowieka itd. Wyka mnie okropnie ściskał - no i wszyscy, wszyscy ${ }^{31}$.

\section{List do Jerzego Andrzejewskiego i do „Katechumenów”}

Miesiąc później zasiadł do pisania, by w końcu zmierzyć się z wyzwaniem, jakie stanowiły dla niego Propozycje teraźniejszości. W końcu grudnia 1947 roku Kantata anielska była już ukończona. Swój ślad odcisnęły na eseju święta Bożego Narodzenia i fraza zaczerpnięta z popularnej kolędy: „Pokój ludziom dobrej woli". To właśnie te słowa anielskiego pozdrowienia zdecydowały o tytule i klimacie przygotowywanego tekstu ${ }^{32}$.

\footnotetext{
30 W dzienniku pisarza czytamy: „Laski - to moja duchowa ojczyzna. Całe ukształtowanie wewnątrz - religijne zawdzięczam temu miejscu i ludziom tutejszym: Marylskiemu, s. Teresie [Landy], s. Katarzynie [Steinberg]. Mieszkam w bibliotece, obok pokoju ojca [Władysława] Korniłowicza, gdzie zawsze zatrzymywał się ks. Prymas [S. Wyszyński]" [J. Zawieyski, Dziennik 5 IV 1955, w: tegoż, Dzienniki, t. 1, Warszawa 2011, s. 87].

31 J. Zawieyski, List do S. Trębaczkiewicza z 22 listopada 1947 r., Ossolineum 16453/II vol. 1, s. 403.

32 Zob. J. Zawieyski, Kantata anielska, s. 1; tu m.in.: „doszła nas z czyjegoś radia pieśń kolędowa $z$ refrenem «Gloria». Jest to znana kolęda, w której przewija się kantata anielska, śpiewana przez Aniołów w chwili narodzin Chrystusa. Oddano w niej Bogu chwałę, że zesłał Syna ludziom i ziemi oznajmiono pokój: «Pokój ludziom dobrej woli». Narodzenie Boga przynio-
} 
Rzecz została opublikowana w styczniu następnego roku na łamach „Tygodnika Powszechnego" i już samym zewnętrznym kształtem (półtorej strony objętości i podobne rozłożenie w szpaltach) mogła budzić skojarzenia z Propozycjami teraźniejszości. Podtytuł List do Jerzego Andrzejewskiego i do "Katechumenów" nie tyle zawężał krąg odbiorców, co doprecyzowywał zakres poruszanej problematyki. Religijne wątpliwości Andrzejewskiego potraktowane zostały jako fragment szerszego zjawiska, dynamicznego procesu formowania się światopoglądów osób o wyjątkowej wrażliwości i szerokich horyzontach intelektualnych. Zawieyski sięgał po podobne przykłady z własnego otoczenia i analizował je odwołując się do (wyimaginowanej?) rozmowy z dwojgiem młodych ludzi, przedstawionych jako Maria i Piotr. Sposób, w jaki ta para formułowała swoje przemyślenia, nazywał "spowiedzią niewierzących". Sam sytuował się w roli mistrza - spowiednika i przekonywał, że podobne dylematy przeżywają tylko ci, którzy stawiają sobie najwyższe wymagania moralne. Używając formy "ty" zwracał się bezpośrednio do autora Propozycji teraźniejszości:

Ludzie typu Piotra i Marii nie są intelektualnymi „przyjaciółmi” Kościoła, jak określiłeś pewien typ intelektualistów, zbliżonych do katolicyzmu. W obu tych postawach jest znamię dwóch epok, oddzielonych od siebie wojną, która od ludzi żądała hartu moralnego, mniej natomiast, lub wcale, intelektualnych sprawności. [...] Dziś ci „intelektualni przyjaciele Kościoła” musieli się opowiedzieć albo za marksizmem, albo za katolicyzmem. Nie oznacza to wcale, by postawa „środka” nie istniała i by Kościół nie miał swoich katechumenów. [...] Zdaje się, że cała różnica pomiędzy wczoraj a dziś polega na stopniu „zaangażowania się", na moralnej odpowiedzialności za siebie i za całość. Słusznie więc stawiają sobie i sprawie, do której się garną, wymagania najwyższe ${ }^{33}$.

Cezurę drugiej wojny światowej, którą Andrzejewski łączył ze schyłkiem świata kształtowanego przez myśl katolicką, Zawieyski postrzegał inaczej. Twierdził, że pod naporem zła doszło do konsolidacji pozytywnych wartości, rozproszonych wcześniej i używanych przez ludzi do mniej ważnych celów. Chrześcijaństwo według niego nie obiecywało niwelowania cierpienia. Dawało jedynie nadzieję, że wspólnota działań opartych na dobrej woli będzie siłą zdolną przezwyciężyć skutki katastrof, jakie sprowadza na siebie ludzkość. Nieuchronne upadki stanowiły w tej koncepcji konsekwencję

sło pokój i wezwało do uczestnictwa w nim wszystkich, których wola kieruje się ku dobru. Jest to pozdrowienie ludzkości i jest to Chrzest, przez który wchodzi do Chrystusa każdy, kto dobru pragnie służyć i pokój czynić. Na woli ku dobru wspierają się fundamenty Kościoła Powszechnego".

33 J. Zawieyski, Kantata anielska, s. 1. 
wolności danej człowiekowi przez Boga. Żeby się z nich podnieść, potrzebna była wiara, że jest to możliwe, że boski pierwiastek dobra znów może się rozwinąć. Za najważniejszą misję Kościoła Zawieyski uważał szerzenie miłości, która zapewnia pokojowe współistnienie jednostek i grup społecznych, narodów i ras. Ten ewangeliczny nakaz nie miał charakteru ideologicznej ekspansji. Powinien być realizowany „słowem, argumentacją intelektualną, lecz nade wszystko pełnią cnót moralnych i potęgą Łaski" ${ }^{34}$. Marksizmowi eseista przyznawał status „prawdy niecałkowitej”, ale „w pełni akceptowanej przez chrześcijaństwo" ${ }^{35}$. Dostrzegał wartość i zasługi tych, którzy podzielali ten światopogląd i byli otwarci na inne racje.

Kończąc ten wywód, pisał:

Adresuję te rozważania, właściwie te monologi wewnętrzne o cierpieniu chrześcijanina, do Ciebie, drogi Jerzy, gdyż pierwszy dostrzegłeś zjawisko katechumenów i w swojej wrażliwości pisarza przemyślałeś głęboko zawiłe sprawy teraźniejszości. Czy zechcesz do nich wrócić?

Pisząc do Ciebie, miałem także na myśli bardzo liczny krąg przyjaciół, którym te same sprawy są bliskie. Miałem na myśli moich sprzymierzeńców ideowych, miałem także na myśli moich przeciwników z "Kuźnicy" (Żółkiewskiego, Jastruna, Brandysa), lecz nade wszystko wspomnianych tu $\mathrm{z}$ imienia "katechumenów".

Niech przyjmą te uwagi jako pozdrowienie braterskie ${ }^{36}$.

Andrzejewski uchylił się od odpowiedzi na rzuconą przez Zawieyskiego propozycję spotkania pod „kopułą Powszechnego Kościoła”. Kierunek dyskursu wytyczony w Kantacie anielskiej wpisywał się w nurt oficjalnego życia literackiego jako zaledwie tolerowany, mało szkodliwy, religijny anachronizm. Tak przynajmniej sądzić można na podstawie opinii wystawionej kilka miesięcy później innemu esejowi Zawieyskiego pt. Zmierzch będzie jako południe $^{37}$. Referent Marian Żychowski, z Głównego Urzędu Kontroli Prasy, Publikacji i Widowisk (GUKPPiW) dostrzegł w tym utworze nawiązania do książki Étienne Gilsona Le thomisme i dramatu Jean-Paula Sartre'a Les Mains sales oraz wychwycił echa zjazdu katolickich intelektualistów w Lionie ${ }^{38}$.

\footnotetext{
34 Tamże.

35 Tamże, s. 3.

36 Tamże.

37 J. Zawieyski, Zmierzch będzie jako południe, „Tygodnik Powszechny” 1948, nr 42, s. 1-2.

38 AAN, GUKPPiW, sygn. 122, t. $9 / 19$ a, k. 134. Mowa o: É. Gilson, Le thomisme. Introduction au système de saint Thomas d'Aquin, Vrin 1919 (Tomizm. Wprowadzenie do filozofii św. Tomasza z Akwinu, Warszawa 1960); J.-P. Sartre, Les Mains sales (Brudne ręce; paryska prapremiera dramatu 2 IV 1948 r.).
} 
Wymowę tekstu podsumowywał krótko: „dziwnie jest pojmowana moralność katolicka: «Kochaj i rób co chcesz» (zdanie wyjęte ze św. Augustyna); typowe operowanie erystyką i tautologią" 39 .

W styczniu 1958 roku, gdy Kantata anielska miała być przedrukowana $\mathrm{w}$ autorskim tomie pt. Próby ognia i czasu (pierwotna wersja tytułu: $W$ kręgu wiary $i$ nadziei), oceniano ją w GUKPPiW jako „dyskryminację marksizmu i marksistów" ${ }^{40}$, ale ostatecznie dopuszczono do publikacji.

\section{Ideowe rozdroża Andrzejewskiego}

Powieść Andrzejewskiego pt. Zaraz po wojnie, drukowana w odcinkach w 1947 roku i wydana osobno rok później pt. Popiót i diament ${ }^{41}$, dość powszechnie odebrana została jako ukłon w stronę komunistycznych władz. Fakt, że w lipcu 1948 roku tygodnik „Odrodzenie” uznał ją za najwybitniejszą pozycję literacką minionego roku, jeszcze ten ideologiczny wydźwięk wzmocnił. Krótko po uroczystości wręczenia nagrody ${ }^{42}$ laureat (zamieszkały wówczas w Szczecinie) napisał do Zawieyskiego list utrzymany w zdecydowanie minorowym tonie ${ }^{43}$.

Rozpoczął od tłumaczenia, że wolałby bezpośrednią rozmowę, ale kiedy w czerwcu pukał do drzwi adresata, ten akurat przebywał w Laskach. Przechodząc do meritum stwierdzał:

Twoje przewidywania, mój miły, że z powodu nagrody jestem w świetnym humorze i w nastroju pełnym nadziei i dobroci, są niestety całkowicie fałszywe. Rzeczywistość moja jest całkiem inna, a nastrój i samopoczucie gorsze niż kiedykolwiek w najgorszych chwilach bywały. Wybacz mi trywialność, lecz czuję się mniej więcej tak, jakbym siedział w czarnej, diabelskiej dupie. Oczywiście, tłumacząc to na język laicki, czarną dupą jestem ja sam ${ }^{44}$.

39 AAN, GUKPPiW, sygn. 122, t. 9/19 a, k. 134.

40 AAN, GUKPPiW, sygn. 1809, s. 23. Szerzej o problemach Zawieyskiego z cenzurą zob. B. Tyszkiewicz, Zaangażowanie, presja, cenzura. Z uwarunkowań literackiej i politycznej działalności Jerzego Zawieyskiego po roku 1956, w: Sensus Catholicus. Katolicy świeccy w Polsce Ludowej. Postawy - aktywność - myśl, red. R. Ptaszyński, T. Sikorski, Toruń 2014, s. 438-464.

41 J. Andrzejewski, Zaraz po wojnie, „Odrodzenie” 1947, nr 3-22, druk przerwany; wydanie osobne pt. Popiót $i$ diament, Warszawa 1948. Powieść była wznawiana w Polsce Ludowej ok. 30 razy.

42 Relacja z uroczystości wręczenia nagrody (28 VII 1948 r. w Warszawie) zarejestrowana przez Polską Kronikę Filmową zob. http://www.repozytorium.fn.org.pl/?q=pl/node/5890 [dostęp 20.05.2018].

43 J. Andrzejewski, List do Jerzego Zawieyskiego z 7 IX 1948 r., rękopis w Muzeum Literatury w Warszawie, sygn. 1493, Korespondencja J. Zawieyskiego, t. 1, s. 7-8.

44 Tamże, s. 7. 
Rozwijając tę metaforę, Andrzejewski burzył propagandowy wizerunek nagrodzonego artysty. "Sukcesy, mój stary, schlebiają tylko głupiej próżności” - wyjaśniał - i dodawał, że „lepiej zna swoje braki i niedostatki niż ktokolwiek inny". Przyszłość widział w czarnych barwach, zarówno w zakresie spraw osobistych, jak i w odniesieniu do sytuacji w kraju. Pisał o tym bez najmniejszych ogródek ${ }^{45}$. Dręczyło go przytłaczające uczucie zbliżającej się nieuchronnie katastrofy, które odbierało satysfakcję z udanego życia rodzinnego i rosnącego prestiżu opartego na uznaniu krytyki. Wspominał miliony niepotrzebnych, wojennych śmierci, z których wciąż nie zostały wyciągnięte wnioski. Przekonywał, że trudności pierwszych trzech lat odbudowy powojennych ruin są tylko nikłym przybliżeniem problemów, które dopiero się wypiętrzają. Marksistowskie widzenie historii i procesów społecznych, które teoretycznie sobie przyswoił, nic w tej diagnozie nie zmieniało. Był niezdolny, by dopasować się do tej optyki i metod działania. Budował przerażającą wizję rzeczywistości, w której zabrakło dla niego miejsca:

Doszedłem już do tego, że rozumiem całą bezwzględną i okrutną dialektykę terroru, lecz cóż ja - z urodzenia, z temperamentu, z uczucia moralista - mam na terrorze budować? To już jest chodzenie nad przepaściami ${ }^{46}$.

Uprzedzając spodziewaną reakcję i argumenty Zawieyskiego, natychmiast dodawał:

Ty oczywiście masz na to wszystko lekarstwo. Ale to nie dla mnie. Silniej niż kiedykolwiek zdaję sobie sprawę, że na Twojej drodze nie robię ani jednego kroku. Nawet Ci zresztą nie zazdroszczę Twojej wiary. A poza tym Ty też dźwigasz na plecach dość ciężarów, każdy ma swój tobół ${ }^{47}$.

Kończył list już bardziej konwencjonalnie: wspomnieniem żony i dzieci, pochwałą domu $\mathrm{z}$ ogrodem $\mathrm{w}$ sąsiedztwie lasu i jeziora. Tylko problemy z własnym zdrowiem i dokuczliwy ból (chwilowo zaleczony w szpitalu) znów mąciły tę harmonię. „Muszę się najpierw i fizycznie i nerwowo pozbierać" - pisał - i dołączał pozdrowienia. Mimo zażyłości cechującej tę korespondencję, bezpośrednia wymiana zdań między pisarzami stawała się coraz rzadsza. Z ustaleń Anny Synoradzkiej-Domadre wynika, że Agnieszka

\footnotetext{
45 „Ściana trudności, którą widzę przed sobą i jako człowiekiem, i co za tym idzie - jako pisarzem, jest tak ogromna i mroczna[?], iż chwilami nie ma we mnie nic prócz zwątpień i znużenia" [tamże, s. 7].

46 Tamże, s. 7.

47 Tamże, s. 7-8.
} 
Andrzejewska uważała kontakty z jej ojcem chrzestnym za nikłe ${ }^{48}$. Zaważyły na tym decyzje podejmowane $w$ ostatnich latach stalinowskich, kiedy Andrzejewski dopasował się do wymogów socrealizmu i czerpał profity z państwowego mecenatu, Zawieyski zaś rozwijał twórczość, której odmawiano prawa do rozpowszechniania.

\section{„Przed” i „po” październiku 1956}

Postępy politycznej „odwilży” śledzili z dwóch stron ideologicznego frontu ${ }^{49}$. O sprawach natury osobistej dowiadywali się za pośrednictwem osób trzecich. „Podobno - relacjonował Zawieyski w maju 1955 roku - Jerzy Andrzejewski przeżywa obrzydzenie do ustroju i do partii. Pije, nic nie pisze, męczy się. Bardzo mi go żal" 50. Niespełna miesiąc później zapisał w dzienniku:

Herbert przytaczał zdanie Andrzejewskiego, że prawdziwym dramatem współczesności mógłby być dramat marksisty - pisarza. Nieco w tym megalomanii i przesady. Cóż wiąże pisarza marksistę z partią, komunizmem i tym, w co w ogóle nie wierzy? Strach. Lęk przed cierpieniem i przed konsekwencjami jakiejś męskiej postawy. Właściwie jest to dość żałosne, może budzić współczucie, w krańcowych formach litość. Andrzejewski ze strachu i pod presją wybrał swoją drogę i pod strachem, w obrzydzeniu, na niej trwa. Nie zdobędzie się na nic, na żaden akt decyzji, bo trochę się też lubuje swoimi konfliktami. Ale doprawdy żal mi go. To wielki talent, który się marnuje ${ }^{51}$.

Współczucie to przybrało na sile, gdy twórczość Andrzejewskiego znalazła się na celowniku marksistowskiej krytyki. Kiedy w czerwcu 1955 roku Tadeusz Drewnowski zdyskredytował książkę pt. Partia i twórczość pisarza ${ }^{52}$,

48 Zob. M. Synoradzka-Demadre, Jerzy Andrzejewski. Przyczynek do biografii prywatnej, s. 292, 638.

49 Relacjonując zebranie w ZLP, zwołane przez partyjną egzekutywę 13 IV 1955 r., Zawieyski notował: „Atakowałem niski poziom referatów, najczęściej przypadkowo werbowanych, byle zapełnić statystykę zebrań. Powiedziałem też, że na zebraniach ideologicznych pisarze byli wzywani do posłuchu i podporządkowania się. Nikomu nie chodziło o przekonywanie, zasadą był pośpiech, niecierpliwość i natychmiastowa realizacja postulatów realizmu socjalistycznego. [...] Uporczywie patrzył na mnie Andrzejewski, ale nie mogłem nic wyczytać z jego wzroku. Na pewno nie potwierdzał tego, co mówiłem" [J. Zawieyski, Dzienniki, t. 1, Warszawa 2011, s. 90].

50 J. Zawieyski, Dzienniki, s. 102. Notatki z 18 V 1955 r.

51 Tamże, s. 113-114. Notatki z 12 VI 1955 r.

52 Tamże, s. 116. Notatki z 19 VI 1955 r. Mowa o: J. Andrzejewski, Partia i twórczość pisarza, Warszawa 1952. Krytykę tej pozycji (przedstawioną najpierw na zebraniu ZLP) T. Drewnowski zawarł w artykule pt. O kilku „odmianach" krytycyzmu w literaturze, „Nowa Kultura” 1955, nr 25. 
Zawieyski uznał stawiane przez recenzenta zarzuty za makiaweliczne. Ich przewrotność poległa na tym, że cięgi dosięgały wykonawcę partyjno-państwowych instrukcji, omijały zaś władze, które je wydały. Komentując tę sytuację $\mathrm{w}$ diariuszu, pisał:

Andrzejewski jest konsekwentny w swej broszurze i na pewno się nie mylił, tak pisząc. To właśnie partia zmieniła swój pogląd i to partia uczyniła woltę w innym kierunku. Mimo że nie mogę podzielać poglądów Andrzejewskiego, doskonale go rozumiem i wszelkie ataki na niego powodują, że staję po jego stronie $^{53}$.

Zawieyski nie tylko był solidarny z twórcą osaczanym przez niedawnych stronników, ale dostrzegał też pozytywy w jego najnowszym dorobku. Z uznaniem wyrażał się o eseju pt. Trzykrotnie nad "Lordem Jimem"54, potraktowanym jako świadectwo światopoglądowej ewolucji niedawnego marksisty, który - niezależnie od politycznych wyborów - był wybitnym artystą. W lipcu 1956 roku spotkał w Paryżu Czesława Miłosza i odniósł wrażenie, że ten podziela jego opinię o autorze Popiołu $i$ diamentu ${ }^{55}$. Miesiąc później gościł Andrzejewskiego w swoim warszawskim mieszkaniu i relacjonował mu przebieg tej paryskiej rozmowy, a przy okazji przejął od niego głęboki pesymizm w ocenie rozwoju wydarzeń społeczno-politycznych ${ }^{56}$.

Zmiany, jakie zaszły w kraju po październiku 1956 roku, nie wpłynęły znacząco na intensywność i charakter kontaktów między Andrzejewskim i Zawieyskim. Ten pierwszy, wybrany w grudniu 1956 roku prezesem stołecznego oddziału ZLP, coraz bardziej konfrontował się z polityką kulturalną władz. Był zaangażowany w przygotowanie miesięcznika „Europa” i jesienią 1957 roku - z chwilą zawieszenia pisma - oddał legitymację PZPR. W 1964 roku należał do sygnatariuszy tzw. „Listu 34”, wystosowanego $\mathrm{w}$ proteście przeciwko represjom i ograniczeniom dotykającym środowiska twórcze ${ }^{57}$. Zawieyski, choć 1 grudnia 1963 roku był

53 J. Zawieyski, Dzienniki, s. 116. Notatki z 19 VI 1955 r.

54 J. Andrzejewski, Trzykrotnie nad „Lordem Jimem”, „Twórczość” 1956, nr 2. Na ten temat zob. J. Zawieyski, Dzienniki, s. 203, notatki z 3 III 1956 r.

55 J. Zawieyski, Dzienniki, s. 271, notatki z 23 VII 1956 r. Tu m.in.: „Dziwiło mnie, że [Miłosz] dopytywał wiele razy o Andrzejewskiego. Widocznie to jedyny pisarz, na którym mu w kraju zależy. Nadto ma w stosunku do niego wyrzuty sumienia za portret w Zniewolonym umyśle".

56 Tamże, s. 284, notatki z 30 VIII 1956 r.

57 Szerzej na temat okoliczności powstania i charakteru tego dwuzdaniowego pisma, które w marcu 1964 r. Antoni Słonimski złożył w Urzędzie Rady Ministrów, zob. List 34 pół wieku później. Wystawa internetowa Muzeum Literatury [on-line], http://list34.muzeumliteratury.pl/ [dostęp 29.05.2018]. 
uczestnikiem zebrania (w mieszkaniu Andrzejewskiego), na którym zainicjowano przygotowanie owego memoriału ${ }^{58}$, ostatecznej wersji dokumentu nie parafował.

W diariuszu zapisał, że „zebranie było ważne, a nawet konieczne" 59, zaś jako wieloletni członek zarządów ZLP i Pen Clubu znał i rozumiał podnoszone przez kolegów problemy. Ważył jednak swoje decyzje już nie jako osoba prywatna i niezależny artysta. Od października 1956 roku reprezentował warszawski Klub Inteligencji Katolickiej, a w 1957 roku został wybrany posłem na Sejm i członkiem Rady Państwa PRL. Przez ponad dekadę współtworzył politykę koła posłów katolickich „Znak” i za aprobatą prymasa Stefana Wyszyńskiego mediował na rzecz normalizacji stosunków Kościół - państwo. W roli nieformalnego rzecznika dialogu katolików i marksistów wytrwał aż do tragicznego zgonu w 1969 roku. Nie zmienił tego fakt, że kwietniu 1968 roku (gdy podtrzymał w mowie sejmowej zasadność interpelacji z 11 marca w sprawie represjonowanej młodzieży akademickiej ${ }^{60}$ odwołany został z funkcji członka Rady Państwa. Definitywnie pozbawiono go możliwości działania w kwietniu 1969 roku, gdy tuż przed wygaśnięciem poselskiego mandatu, decyzją władz partyjno-państwowych stracił prawo do ponownego kandydowania ${ }^{61}$. Wkrótce potem doznał udaru mózgu i niespełna dwa miesiące później (o świcie 18 czerwca 1969 roku) upadkiem z okna czwartego piętra rządowej kliniki przy ul. Emilii Plater zakończył życie. Okoliczności, w jakich do tego doszło, pozostały niewyjaśnione.

58 Zob. J. Zawieyski, Dzienniki, t. 2, s. 354-355. Notatki z 1 XII 1963 r. Według tej relacji poza gospodarzem w spotkaniu uczestniczyli także: Maria Dąbrowska, Anna Kowalska, Adam Ważyk, Mieczysław Jastrun, Paweł Jasienica, Stefan Kisielewski, Zygmunt Mycielski, Witold Wirpsza, Melchior Wańkowicz, Stanisław Mackiewicz, Juliusz Żuławski, Henryk Krzeczkowski.

59 Tamże, s. 355.

60 Treść interpelacji (złożonej na ręce premiera Józefa Cyrankiewicza) sprowadzała się do zapytania, co rząd zamierza uczynić, aby powściągnąć brutalną akcję milicji i ORMO skierowaną przeciw młodzieży akademickiej oraz jaką odpowiedź dostanie młodzież pytająca o demokratyczne swobody i politykę kulturalną PRL. Pod interpelacją podpisali się posłowie koła "Znak": Konstanty Łubieński, Tadeusz Mazowiecki, Stanisław Stomma, Janusz Zabłocki i Jerzy Zawieyski. Członkostwa w Radzie Państwa Zawieyski został pozbawiony w głosowaniu sejmowym, nazajutrz po mowie wygłoszonej 10 kwietnia $1968 \mathrm{r}$.

61 Decyzja w tej sprawie zapadła w KC PZPR, a zakomunikowana została przez Zenona Kliszkę (wicemarszałka Sejmu i sekretarza KC PZPR) Stanisławowi Stommie (przewodniczącemu koła „Znak”). Zawieyski tak to relacjonował 9 IV 1969 r.: „Kliszko ze Stommą rozmawiał 5 minut i oświadczył, że partia godzi się na wszystkich posłów «Znaku» z wyjątkiem mnie" [J. Zawieyski, Dzienniki, t. 2, s. 855]. 


\section{Wznowiony dialog}

Dopiero ostatni, opublikowany już pośmiertnie, zbiór esejów Zawieyskiego pt. Korzenie ${ }^{62}$ poruszył estetyczną wrażliwość Andrzejewskiego. Po części była w tym zasługa Tomasza Burka, który zrecenzował ów tom na łamach „Twórczości” 63. Fragmenty tej recenzji - ujęte jako zapiski z dziennika z 9 kwietnia 1970 roku - włączone zostały do Prologu powstającej wówczas Miazgi. Po zapowiedzi:

W ostatniej marcowej „Twórczości”, w artykule Tomasza Burka o Korzeniach Jerzego Zawieyskiego fragment, jakby dosłownie (lecz nie dosłownie stylistycznie) wyjęty mi spod pióra:

rozpoczynał się obszerny cytat:

To, czego szukaliśmy dotąd w literaturze i co w niej podziwialiśmy, to były „kwiaty" i „korony": dzieła, które osiągnęły własną nieosiągalną granicę, spełniały się $\mathrm{w}$ bujności i szumie nieprzeliczonego listowia, znajdowały końcowy wyraz we wspaniałej równowadze trwania i ruchu, w tak zwanej skończonej formie. Model wrażliwości zmieniał się jednak. Formą, która dzisiaj największą przyciąga uwagę i zahacza o nasze fermenty zagadnieniowe, jest to, co z punktu widzenia "korony” zdawać się musi niedokonaniem, zaledwie jej stadium wstępnym, w którym się nawet nie rozpoznaje, jakby złośliwą parodią całości i skończoności: czy nie tym są „korzenie”? ${ }^{64}$

Można zaryzykować twierdzenie, że rozbieżny ogląd rzeczywistości i zupełnie inne wybory życiowe obu pisarzy zbiegły się w punkcie definiowanym jako doświadczenie klęski. Argumentów ku temu dostarcza dalszy ciąg (cytowanej w Miazdze) wypowiedzi Burka:

Zagadnieniem bowiem prawdziwym współczesnego świata i nas, którzy mamy w nim swe miejsce, jest klęska. Nieustająca klęska świadomości, która musi godzić się z rzeczami, z jakimi nie powinna się pogodzić ze stanowiska swych fundamentów moralnych, rozwierająca się przepaść między realnymi możliwościami człowieka a jego powinnościami, którym nie jest w stanie sprostać, cień, który kładzie się w poprzek drogi od „korzenia” do „kwiatu”, rozrywa związki pomiędzy ludźmi, ludźmi i ludźmi, ludźmi i rzeczami, przecina niewidzialne kanały, którymi płynie niewymienialna na nic innego krew miłości i sympatii,

\footnotetext{
62 J. Zawieyski, Korzenie, Warszawa 1969.

63 Zob. T. Burek, Bruliony wielkich tematów, „Twórczość” 1970, nr 3, s. 101-110.

64 J. Andrzejewski, Miazga, Wrocław 2002, s. 207-208 oraz LXXXII. Cytat w powieści za T. Burek, Bruliony wielkich tematów, s. 101-110.
} 
to one spychają sztukę ku „korzeniom" i znajdują swój wykładnik w formach "niedociągniętych", otamowanych, zatrzymanych w stadium wstępnym, „brulionowym" 65 .

W takiej interpretacji przegrana (lub choćby tylko niespełnienie) człowieka, rozdartego między wskazaniami moralnej busoli i wymogami ułomnej rzeczywistości, stanowiła o sile artysty. Sztuka - pojmowana jako odsłanianie wewnętrznych uwikłań w funkcjonowaniu jednostki i zbiorowości jałowiała, sprowadzona do zachwytu nad sukcesem „kwiatu”. W tym względzie Andrzejewski zgadzał się z Zawieyskim. Żeby podjąć refleksję, do jakiej zachęcała Kantata anielska, potrzebował jeszcze czasu.

W styczniu 1977 roku zdecydował się na odwiedziny w ośrodku zakonnym w Laskach. Był to rodzaj ucieczki przed samotnością i chorobą alkoholową, przed frustracją problemami twórczymi i zmaganiami z cenzurą, a przede wszystkim - przed szykanami ze strony PRL-owskich służb nękających opozycyjnego literata. Wobec władz stwarzał wrażenie, że zapraszają go franciszkanki, bo, jak wyjaśniał przy innej okazji - „miał zbyt wielki szacunek do Kościoła”, by ostentacyjnie się z nim „bratać” ${ }^{66}$. O pomoc w kwestiach organizacyjnych zwrócił się do Bogusława Wita ${ }^{67}$, obdarzonego niegdyś zaufaniem Zawieyskiego i wciąż mile widzianego w Laskach. Wkrótce potem do Departamentu IV, Wydziału II Ministerstwa Spraw Wewnętrznych spłynęło doniesienie tajnego współpracownika o pseudonimie „Krzysztof”, który m.in. informował, że:

Andrzejewski prosi mnie, abym wpłynął na siostry Katarzynę i Marię (zna je obie z lat 1936-1939), aby zaproszony został do Lasek w lutym lub pod koniec stycznia na dwa tygodnie do pokoju Zawieyskiego. Prosi bym napisał list do s. Katarzyny i nie przez pocztę go Katarzynie doręczył (poczta jest pod nadzorem) aby Katarzyna zatelefonowała do niego z zaproszeniem. Bezpieka

\footnotetext{
65 Tamże.

66 Z materiałów zachowanych w Instytucie Pamięci Narodowej w Warszawie (IPN), teczka oznaczona sygnaturą IPN BU 0204/1704/2, Wyciąg z doniesienia źródła «Krzysztof» z 7. I 1977 r. Tak tłumaczył odmowę przyjęcia zaproszenia ojców Paulinów do udziału w sesji literacko-naukowej, organizowanej $\mathrm{w}$ jasnogórskim klasztorze.

67 Bogusław Wit (rodowe nazwisko Wyrostkiewicz), 1946-1984, publicysta i krytyk teatralny, autor wierszy. Poznany przez Zawieyskiego latem 1968 r. (jako student wydziału filozoficznego warszawskiej Akademii Teologii Katolickiej i kierownik literacki teatru działającego przy tej uczelni) był później opiekunem i edytorem spuścizny literackiej pisarza. Inwigilacyjne aspekty oraz homoseksualny charakter tej relacji, a także związki Wita z Andrzejewskim, stały się przedmiotem reporterskich dociekań Joanny Siedleckiej. Zob. J. Siedlecka, Biografie odtajnione. Z archiwów literackich bezpieki, Poznań 2015 (tu rozdziały: Scheda po Jerzusiu, s. 213-247, Zmiażdżyli go na miazge, s. 291-318).
} 
słuchająca jego rozmowy pomyśli, że to Laski są inicjatywą. Wówczas on z Lasek, z pokoju Zawieyskiego nawiąże tak, aby przez s. Marię i s. Katarzynę aby prymas „przypadkiem” był w Laskach i tam w pokoju Zawieyskiego odbył z nim rozmowę. Andrzejewski zdradził mi pod największym sekretem, iż już dwa razy ks. Zieja sugerował, iż prymas chętnie spotka się z nim ${ }^{68}$.

W relacjach „Krzysztofa” z około dwóch tygodni (na przełomie stycznia i lutego 1977 roku) spędzonych przez Andrzejewskiego w Laskach problematyka religijna schodziła na dalszy plan. Dominowała polityka, kłopoty środowisk twórczych i zagadnienia sctricte literackie. A jednak z innych przekazów wynikało, że kwestie wiary absorbowały pisarza bardziej niż pozostałe tematy. W informacji z 27 stycznia 1977 roku czytamy:

Najdłuższa i najbardziej z jego strony ożywiona część rozmowy dotyczyła samych Lasek, ks. Korniłowicza oraz tego, że poszczególni ludzie, księża i zakonnice, w Laskach umierali jako nerwowo chorzy, właściwie szaleni. Andrz.[ejewski] przypisuje to nadmiarowi mistycyzmu, jaki panuje w Laskach. Dużo mówił o [Jerzym] Liebercie. Wydaje mi się, że Andrz.[ejewski] jakby powoli wracał do katolicyzmu ${ }^{69}$.

Istotny w tej notatce jest opis fascynacji mistycyzmem, tyleż obcym naturze Andrzejewskiego, co jakoś dla niego ważnym. Kiedyś uznał, że dla ludzi pozbawionych daru pozazmysłowego, bezpośredniego kontaktu z Bogiem, nie ma miejsca w Kościele. Z tego powodu w Propozycjach teraźniejszości sam wykluczył się ze wspólnoty wierzących. Po prawie trzydziestu latach ostrożnie uchylił zatrzaśnięte niegdyś drzwi.

Jeśli kompleksowo ujmować relacje pomiędzy Andrzejewskim i Zawieyskim, to przedstawione $\mathrm{w}$ artykule fakty przybliżają ważny, ale nie jedyny wymiar problemu. Kantata anielska była ogniwem polemiki prowadzonej na płaszczyźnie dysputy filozoficzno-ideowej, z pominięciem spornych kwestii innej natury. Już poprzez metaforyczny tytuł Zawieyski sytuował pole dyskursu w obrębie sfery sacrum i sygnalizował, że interesuje go porozumienie, a nie konfrontacja. $W$ tym ujęciu dalsze różnice między pisarzami (czy to $\mathrm{w}$ zakresie statusu materialnego, możliwości rozpowszechniania utworów,

\footnotetext{
68 IPN BU 0204/1704/2, Wyciąg z doniesienia źródła «Krzysztof» z 7. I 1977 r.

69 Tamże. Informacja opracowana na podstawie źródła: Konsultant pseudonim „33” z 27 I $1977 \mathrm{r}$.
} 
przynależności organizacyjnej, stosunku do władz politycznych i hierarchii kościelnej, życia towarzyskiego lub rodzinnego) mogły zostać zignorowane.

$\mathrm{Na}$ charakter intelektualno-emocjonalnej więzi łączącej Zawieyskiego z Andrzejewskim niewątpliwie miały wpływ również czynniki z kategorii profanum, a zwłaszcza ich nienormatywna orientacja seksualna. Zarówno ukryty homoseksualista (Zawieyski), jak i lekceważący obyczajowe konwenanse biseksualista (Andrzejewski), obawiali się społecznego wykluczenia, lecz podchodzili do tego zagrożenia inaczej. Wyjaśnienie tych uwikłań to temat na osobną pracę. Ogłoszony drukiem i oddany w seraficznej tonacji dialog katolika z marksistą to jedynie awers zagadnienia.

\section{Bibliografia}

Andrzejewski Jerzy (1937, 1938), Ład serca. Powieść, „Prosto z mostu”, nr 46-57; nr $1-21$.

Andrzejewski Jerzy (1938), Ład serca. Warszawa: Towarzystwo Wydawnicze „Rój”.

Andrzejewski Jerzy (1945), O obronę człowieka, „Odrodzenie", nr 38, s. 6.

Andrzejewski Jerzy (1945), Propozycje teraźniejszości, „Odrodzenie”, nr 45, s. 1, 2.

Andrzejewski Jerzy (1947), Zaraz po wojnie, „Odrodzenie”, nr 3-22.

Andrzejewski Jerzy (1948), Popiół i diament, Warszawa: Czytelnik.

Andrzejewski Jerzy (1956), Trzykrotnie nad "Lordem Jimem”, „Twórczość”, nr 2, s. $147-159$.

Andrzejewski Jerzy (2002), Miazga, oprac. A. Synoradzka-Demadre, Wrocław: Zakład Narodowy im. Ossolińskich.

Baranowski Ludwik (1945), Katastrofizm Andrzejewskiego, „Dziś i Jutro”, nr 3, s. 3-4.

Bąk Wojciech (1945), Konie trojanskie, „Odra”, nr 8, s. 3.

Burek Tomasz (1970), Bruliony wielkich tematów, „Twórczość”, nr 3, s. 101-110.

Kott Jan (1945), Rozmowa, „Odrodzenie”, nr 36, s. 7.

Siedlecka Joanna (2015), Scheda po Jerzusiu; Zmiażdżyli go na miazge, w: J. Siedlecka, Biografie odtajnione. Z archiwów literackich bezpieki, Poznań: Wydawnictwo Zysk i S-ka.

Solski Ludwik (Ludwik Napoleon Sosnowski) (1956), Wspomnienia 1. Na podstawie rozmów napisał Alfred Woycicki, t. 2: 1899-1954, Kraków: Wydawnictwo Literackie.

Synoradzka Anna (1997), Andrzejewski, Kraków: Wydawnictwo Literackie.

Synoradzka-Demadre Anna (2016), Andrzejewski w poszukiwaniu tadu wewnętrznego (1937), w: A. Synoradzka-Demadre, Jerzy Andrzejezwski. Przyczynek do biografii prywatnej, Warszawa: Wydawnictwo Krytyki Politycznej, s. 82-90.

Tyszkiewicz Barbara (2014), Zaangażowanie, presja, cenzura. Z uwarunkowań literackiej i politycznej działalności Jerzego Zawieyskiego po roku 1956, w: Sensus Catholicus. Katolicy świeccy w Polsce Ludowej. Postawy - aktywność - myśl, red. R. Ptaszyński, T. Sikorski, Toruń: Wydawnictwo Adam Marszałek, s. 438-464. 
Zawieyski Jerzy (1932), Gdzie jesteś, przyjacielu?... Warszawa: F. Hoesick.

Zawieyski Jerzy (1934), Daleko do rana, Warszawa: F. Hoesick.

Zawieyski Jerzy (1946), Droga do domu, Warszawa: Wydawnictwo E. Kuthan.

Zawieyski Jerzy (1948), Kantata anielska. List do Jerzego Andrzejewskiego i do "Katechumenów”, "Tygodnik Powszechny”, nr 4, s. 1, 3.

Zawieyski Jerzy (1948), Zagadnienie literatury katolickiej, „Tygodnik Powszechny”, nr 23, s. 1, 3-4.

Zawieyski Jerzy (1948), Zmierzch będzie jako południe, „Tygodnik Powszechny”, nr 42, s. $1-2$.

Zawieyski Jerzy (1960), Powrót Przełęckiego. Dalsze losy bohaterów komedii St. Żeromskiego pt. „Uciekła mi przepióreczka..., Warszawa: Państwowy Instytut Wydawniczy.

Zawieyski Jerzy (1969), Korzenie, Warszawa: Czytelnik.

Zawieyski Jerzy (1971), Kantata anielska. List do Jerzego Andrzejewskiego i do „Katechumenów", w: J. Zawieyski, Droga katechumena, Warszawa 1971, s. 3-15.

Zawieyski Jerzy (1971), Zagadnienie literatury katolickiej, w tegoż: Droga katechumena, wyb. J. Smosarski, S. Trębaczkiewicz, Warszawa: Biblioteka Więzi; Kraków: "Znak", s. 128-151.

Zawieyski Jerzy (2011), Dzienniki, t. 1, Wybór z lat 1955-1959, wyb. i oprac., red. A. Knyt, współpraca M. Czoch, Warszawa: Ośrodek Karta; Dom Spotkań z Historią.

Zawieyski Jerzy (2012), Dzienniki, t. 2, Wybór z lat 1960-1969, wyb. i oprac., red. A. Knyt, współpraca M. Czoch, Warszawa: Ośrodek Karta; Instytut Pamięci Narodowej - Komisja Ścigania Zbrodni Przeciwko Narodowi Polskiemu.

Żółkiewski Stefan (1945), Głos marksisty, „Odrodzenie”, nr 51, s. 1.

\title{
Kantata anielska, or a Polemical Dialogue between Zawieyski and Andrzejewski
}

\begin{abstract}
The article addresses the polemic between two Polish writers Jerzy Andrzejewski and Jerzy Zawieyski, whose outlook was significantly affected by the war experience. When in 1945 Andrzejewski was influenced by Marxist ideology, Zawieyski turned to religion and gained recognition as a Catholic writer. The author of the article asserts that Andrzejewski's Propozycje teraźniejszości (published after 1945) and Zawieyski's Kantata anielska (1948) represent a literary polemic determined by its biographical and socio-political contexts.
\end{abstract}

Keywords: literature of Polish People's Republic, cultural policy, literary polemics, biographical writing 